\title{
Ecology, Morphology, Distribution, and Use of Sesbania tchadica (Sesbania Sesban) from the Republic of Chad: A Review
}

Ousman Brahim Mahamat ( $\sim$ ousman.brahim@uae.ac.ma )

Abdelmalek Essaâdi University

\section{Saoud Younes}

Abdelmalek Essaâdi University

Boy Brahim Otchom

NखDjamena University

Steve Franzel

International Centre for Research in Agroforestry: World Agroforestry Centre

Al-Djazouli Ouchar Mahamat

Abdelmalek Essaâdi University

Asraoui Fadoua

Abdelmalek Essaâdi University

El ismaili Soumaya

Abdelmalek Essaâdi University

\section{Systematic Review}

Keywords: Sesbania tchadica (Sesbania sesban), leguminosae, morphology, distribution, flora of Chad, fertilizer soil plant, medicinal plants

Posted Date: May 20th, 2021

DOI: https://doi.org/10.21203/rs.3.rs-543115/v1

License: (c) (1) This work is licensed under a Creative Commons Attribution 4.0 International License.

Read Full License 


\section{Ecology, Morphology, Distribution, and Use of Sesbania tchadica (Sesbania Sesban)}

\section{from the Republic of Chad: A Review.}

Ousman Brahim Mahamat ${ }^{1}$, Saoud Younes ${ }^{1}$, Boy Brahim Otchom ${ }^{2}$ Steve Franzel $^{3}$, Al-Djazouli Ouchar Mahamat ${ }^{4}$, Asraoui

Fadoua $^{1}$, El ismaili Soumaya ${ }^{5}$

${ }^{1}$ Laboratory of Applied Biology and Pathology, Faculty of Sciences, Abdelmalek Essaâdi University, Tetouan, Morocco.

${ }^{2}$ Natural Substances Research Laboratory, Faculty of Exact and Applied Sciences, N'Djamena University, Republic of Chad.

${ }^{3}$ International Centre for Research in Agroforestry: World Agroforestry Centre, Consultative Group on International Agricultural Research, Nairobi, Kenya.

${ }^{4}$ Laboratory of Geology and Oceanology, Department of Geology, Faculty of Sciences, Abdelmalek Essaâdi University.

${ }^{5}$ Innovating Technologies Laboratory, civil engineering department, National School of Applied Sciences ENSA-Tangier, Abdelmalek Essaâdi University.

Key message: A review of literature of potential uses and a survey study about the tree Sesbania tchadica (Sesbania Sesban) leguminous native from the Republic of Chad are described in this paper.

Abstract: This study on the leguminous plant Sesbania tchadica has made it possible to highlight its description, specification and identification in N'Djamena region S. tchadica (Sesbania Sesban Merr. (L)) is an annual tree that measures more than 4 meters in height. This species is abundant especially in Ndjamena. In most of the district of Ndjamena, S. tchadica was the most common type. S. tchadica shows a rapid early growth and grows well in various soils especially sandy siltstone and silty shale. The local inhabitants use the species in many ways: as a medicine, a livestock feed, for improving soil fertility, for fuelwood and to repel desert encroachment. In this study, various academic publishing websites like Science Direct, Springer Nature, some online international plant databases, and other national data herbaria from the republic of Chad were used to identify, describe and summarize the research literature on Sesbania Sesban. This paper also describes the morphological characteristics observed in Sesbania Sesban from the republic of Chad and its taxonomy to assist in future program evaluations.

Keywords: Sesbania tchadica (Sesbania sesban); leguminosae; morphology; distribution; flora of Chad.

\section{Introduction}

The taxonomic diversity of legumes is enormous. In addition, they provide important benefits to humans including food, medicines, and environmental services. For example, leguminous food grains include beans (Phaseolus vulgaris L.), peas (Pisum sativum L.), soya beans (Glycine max L.), and forage legumes such as clover (Trifolium repens L.), sainfoin (Onobrychis Mill.) and Sesbania sesban. Other legumes are ornamental, (Cercis siliquastrum, Acacia mollissima) melliferous (Robinia pseudoacacia, Melilotus albus), or medicinal (Ceratonia siliqua, Trigonella foenum-graecum, Sesbania sesban). These plants (leguminosae) also fix atmospheric nitrogen via their symbiotic association with soil bacteria, belonging to the genera Rhizobium, Azorhizobium, important crops (Toomsan et al., 2012) (Rochester et al., 2001). They provide nutritious bodybuilding food for man and animals 
complex carbohydrates, minerals, and vitamins essential to good health (Polak et al., 2015) (Maria et al., 2021). They can obtain 35 most of the nitrogen they need from the vast supply of gaseous nitrogen in the air (Cocking, 2000). Air is about 78 percent nitrogen; there are around 6400 kilograms of nitrogen above every hectare of land and water (NifTAL, 1985). These plants gather 37 and use this nitrogen by working symbiotically with special bacteria (rhizobia) in nodules on their roots (Ndoye \& Dreyfus, 1988) 38 (Sharma et al., 2005). Rhizobia infect the root hairs of the leguminous host; nodules develop and become small nitrogen factories on the legume roots. The host plant provides a home for the bacteria and energy to fix or gather air nitrogen. In return, the plant receives fixed nitrogen from the nodule and produces food and forage protein (NifTAL, 1985) (Mmoudiongh. \& Rinaudoe, 1985) (Abdel Magid et al., 1988) (Semba et al., 2021). They also leave fixed nitrogen in the soil for succeeding crops (Dakora F. D. and Keya S. 0., 1997) (Toomsan et al., 2012). Since nitrogen is commonly the most limiting element in food production, and one of the most expensive in fertilizer, this special ability of leguminous crops to work symbiotically with rhizobia to produce protein is becoming increasingly important in world agriculture (Sileshi et al., 2014). Some forage legumes such as Sesbania sp. are used in agroforestry in tropical regions for other purposes such as stakes, fuelwood and reducing soil erosion. Land management practices featuring legumes include cereal-legume intercropping, relay cropping, biomass transfer and fodder banks (Ndungu and Boland, 1994) (Kwesiga et al., 1999) (Orwa et al., 2009) (Sileshi et al., 2014).

In general, leguminous species from arid habitats play a great role in reforestation development programs and in the fight against desertification (Curasson, 1956) (Bashan et al., 2012). They are suitable alone or mixed with other species for use in arid zone agriculture (Bradbury, 1990). Moreover, the integration of legume trees increases yield stability in cropping systems and prevents land degradation (Sileshi et al., 2008) (Sileshi al., 2012). These characteristics give these «fertilizer trees » a very important economic and environmental value (Kiptot et al., 2014).

The genus Sesbania sp. includes many species indigenous to Africa such as S. goetzei, S. keniensis S. rostrata and S. sesban, which possess several desirable characteristics that make them suitable for use as multipurpose trees in farming systems, particularly $S$. sesban (Heering, 1995). Endemic Sesbania sp found in Chad are Sesbania tchadica (Sesbania sesban), Sesbania dalzielii, S. rostrata and others (Jean and Cyrille, 2019).

One of the most serious constraints to the sustainability of agriculture in sub-Saharan Africa is soil nutrient depletion (Bindraban et al., 2012). Many factors cause the decline of soil fertility and carbon stocks of African drylands including deforestation, overgrazing, unsustainable agriculture, and climate change (DeRouw, 1998) (Bakhoum et al., 2018). One of the solutions is the use of mineral fertilizer; however, they are expensive and unsustainable. To address these challenges, scientists have experimented on low cost agroforestry options for soil fertility replenishment (Bindraban et al., 2012). Planting nitrogen fixing trees such as $S$. sesban (S. tchadica) is an effective solution for increasing soil productivity (Bakhoum et al., 2018). The International Center for Agroforestry Research (ICRAF) is interested in the role of Sesbania sesban in improved fallows especially in savannah woodland region (Anon, 1992) (Ndungu and Boland, 1994) (Kwesiga et al., 1999). Improved fallows involve planting mainly legume tree/shrub species in rotation with cultivated crops. In Zambia, ICRAF researchers found that growing Sesbania in depleted agricultural fields or on fallow lands for 2 or 3 years and then introducing a hybrid maize crop after the fallow period produced exciting and encouraging results. Without $\mathrm{N}$ fertilizers, maize yields were $2.3 \mathrm{t}$ ha-1 after 1 year of Sesbania fallow; $5.6 \mathrm{t}$ ha-1, after 2 years; and 6.0 t ha- 1, after 3 years. Continuous maize crops gave only 1.5 t ha-1 (Anonymous, 1985). Shrubs (mostly legumes) and annual crops may be grown together and the shrubs retained as fallows for 2-3 years to improve the soil (Dagar and Tewari, 2017). Afterwards, crops are grown (Kwesiga et al., 1999). Intercropping sweetpotato with other leguminous plants such as Sesbania sesban improves yield of the crop (Muimba-Kankolongo, 2018). Sesbania tchadica (Sesbania Sesban) has many other uses in domestic, environmental, fiber, food, beverages, forage, medicine and wood products and services (Richard and ILDIS, 2018). The objective of this paper is to give a general morphological identification and description of Sesbania tchadica A. Chev. 
from the republic of Chad. This paper provides also an overview and updated information concerning this very useful but lessexploited plant with the purpose to help develop and conserve it.

1- Material and methods:

Study area: N'Djamena is the administrative capital and the largest city of Chad Republic. It is located in the center-west of the country (Figure 1), at the confluence of the Chari and Logone rivers. Its population is estimated in 2020 at 1,422,547 habitants with a total growth rate of the country about 3.69\% (UN, 2021). N'Djamena has a tropical, arid climate, including a long dry season (7 to 8 months, November to May) and a short wet season (3 to 5 months, May to October). Rainfall varies between 400 to 700 $\mathrm{mm} / \mathrm{year}$ with many heavy showers. In recent years, rain falls mainly over a three-month period (July-September). Temperatures observed are between $20^{\circ} \mathrm{C}$ and $45^{\circ} \mathrm{C}$ in the dry season and $18^{\circ} \mathrm{C}$ and $30^{\circ} \mathrm{C}$ in the rainy season $(\mathrm{FAO}, 2012)$.

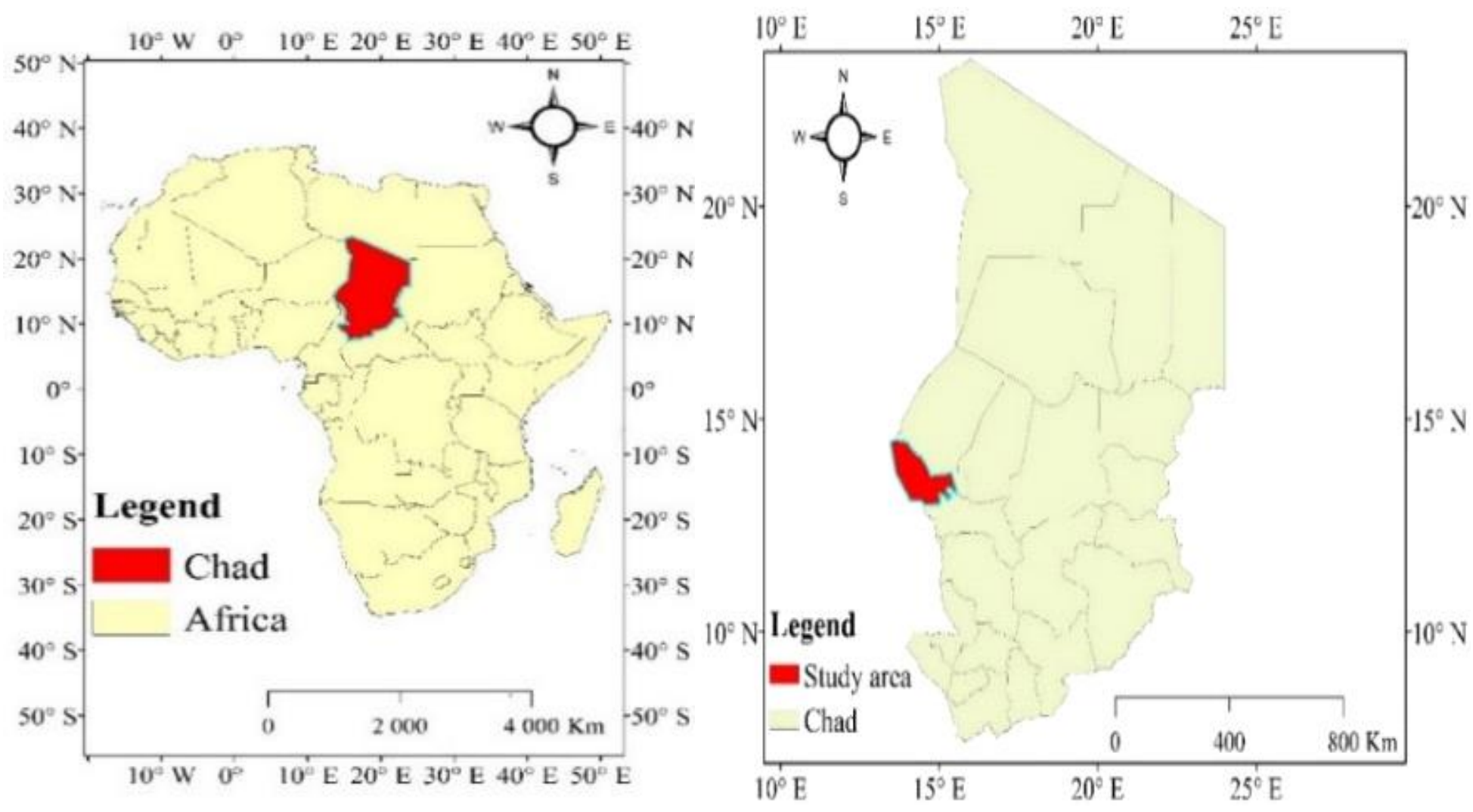

Figure 1: Study area: Map of the Republic Chad and N'Djamena area.

Sampling of the species: The data for this study on Sesbania tchadica (Sesbania sesban) was collected as part of a larger study on medicinal plants of Chad. The morphological determination of Sesbania tchadica is based on the empirical keys determination of plant species (leaves and pods forms, leaves and pods forms, flower form, leaflets form, inflorescence disposition, standard form 88 and position, and plant and branch size). In order to present distinct morphological groups between Sesbania tchadica and other Sesbania sp., leaves and branches were harvested and organized according to their morphology (Figures 6 and 7). The identification and confirmation of the species is based on a comparison of the samples with those of the herbarium of Toumaï Institute, the herbarium of the Livestock Research Institute for Development Institut de Recherche en Elévage pour le Developpement (IRED) (N'Djamena) and assessments by foresters from the National Federation of Associations of Healers and Practitioners of Medicine Fédération Nationale des Associations des Praticiens de la Médicine au Tchad (FENAPMT) (which is under the supervision of the Ministry of Public Health of Chad). The species (Accession number: $N^{\circ} 48$ TI (Toumaï Institute)) is 
registered in the herbariums of the Toumaï Institute, the IRED and then in the Applied Biology and Pathology Laboratory 96 Herbarium (Morocco). The authors also conducted a review of the literature on Sesbania tchadica (Sesbania sesban), its applications in biochemistry and its interactions with other organisms and its environment.

\section{2- Results}

Sesbania tchadica A. Chev. (Augustin Chevalier): "Sesbania" is a Persian term and in the Arabic language is "Saysaban". The original taxon was created by Antonio Jose Cavanilles (1745-1804) and modified by George Bentham in 1859 in his book Flora brasilensis (Gillett, 1963). However, the names "Sesbania" (Auguste, 1913), "Seseban" and "Sesban" already existed (Gillett, 1963). Related names or synonyms are Sesbania Sesban var. nubica, Sesbania sesban Merr. (L) (Ndungu and Boland, 1994) (Baker, 1926) or Sesbania aegyptiaca auct. non Pers. (Jean and Cyrille, 2019). The local name in Chad is Seysaban, Surridj alkoubar or Surridj addougag (Patrice, 1997). The following table shows the taxonomic classification of Sesbania tchadica (table 1).

Table 1: Sesbania tchadica taxonomic classification (Gillett, 1963) ; (Taugourdeau Simon et al., 2019) ; (IPNI, 2020).

\begin{tabular}{|c|c|}
\hline \multicolumn{2}{|c|}{ Sesbania tchadica A. Chev. } \\
\hline Kingdom & Plantae \\
\hline Division & Magnoliophyta or Angiosperms dicotyledonous (Flowering plants) \\
\hline Tribe & Robinieae \\
\hline Classe & Magnoliopsida \\
\hline Order & Fabales \\
\hline Family & Fabaceae \\
\hline Subfamily & Papilionoideae \\
\hline Gender & Sesbania \\
\hline Species & Sesbania Sesban (L.) Merr. (Sesbania tchadica A. Chev.) \\
\hline
\end{tabular}

Range: The genus Sesbania (Fabaceae or Papilionoideae) is composed of annual shrubs and perennial woody plants that are 
Page 5 of $\mathbf{2 5}$

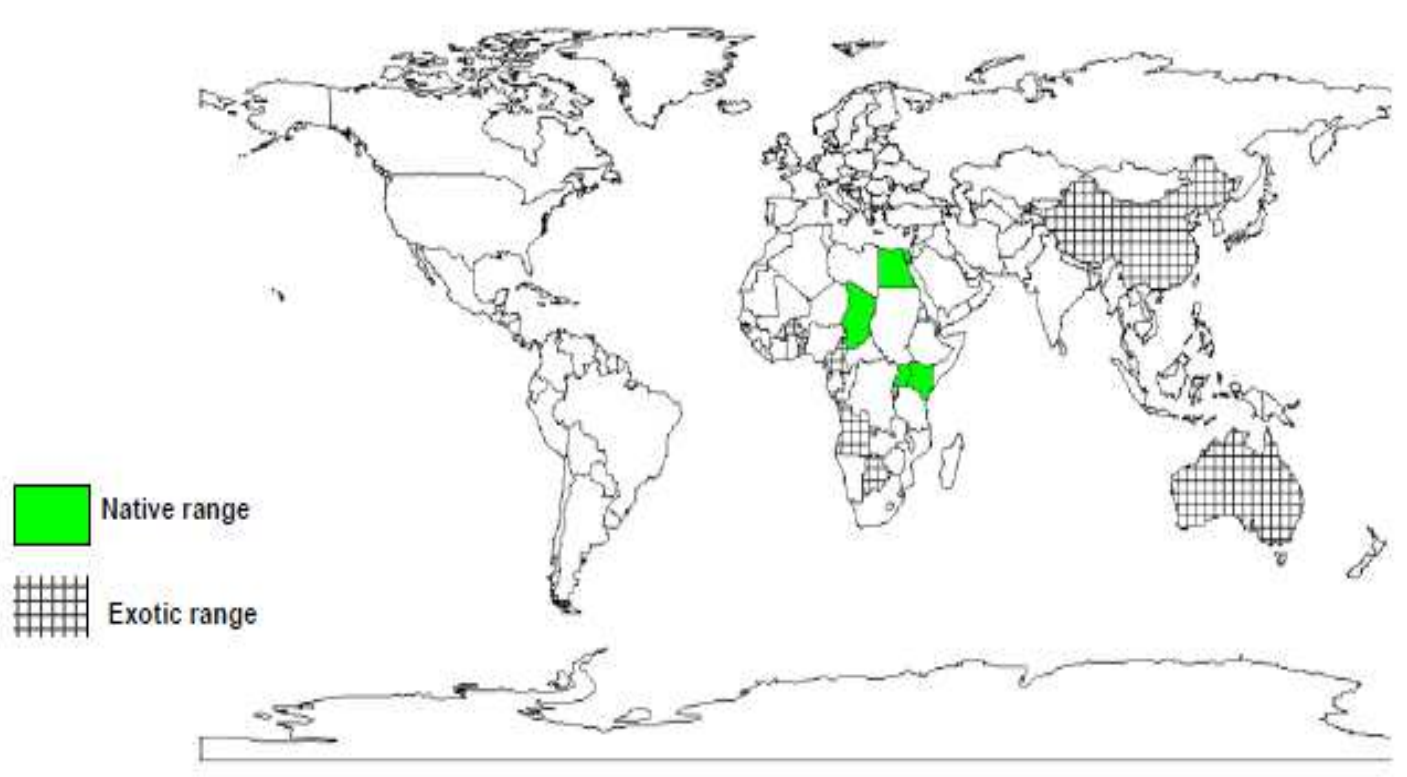

Figure 2: Sesbania sesban Merr. (L) in Chad and others African countries(Orwa et al., 2009).

Habitat and Ecology: Sesbania sesban grows well in the subtropics and in cooler, higher elevation regions of the tropics. It withstands waterlogging and is ideally suited to seasonally-flooded environments (Orwa et al., 2009). It occurs naturally in wet habitats such as lake shores, on muddy river banks and seasonally flooded valley bottoms (Ndungu and Boland, 1994); (Jamnadass et al., 2005). but also grows in open savannah (George \& Gottwald, 2009) and dry, semi-arid zones (Mohammed Abbas et al., 2001). It grows in a wide variety of soils from loose sandy soils to heavy clays (Heuzé et al., 2016). In Chad, especially in N'Djamena, Sesbania tchadica (Sesbania Sesban) often occurred in different types of soil: silt siltstone, limestone, silty shale, sandy soils, and clays (Figure 3B).

Biophysical limits: The mean annual growing temperature of Sesbania sesban is between $18{ }^{\circ} \mathrm{C}$ and $23{ }^{\circ} \mathrm{C}$ (maximum $45{ }^{\circ} \mathrm{C}$ ) and the mean annual rainfall is from 500 to $2000 \mathrm{~mm}$. The mean altitude is between 100 and 2300m. Sesbania tchadica grows at altitude around 300m (Orwa et al., 2009).

Pests and diseases: Sesbania sp is attacked by nematodes, insects, fungi and viruses (Orwa et al., 2009). The leaf-eating beetle Mesoplatys ochroptera can completely defoliate Sesbania leading to mortality. Caterpillars, Hymenoptera, and stem borers attack S. sesban. Some potentially destructive root-knot nematodes have been recorded in India on S. sesban (Orwa et al., 2009). Sesbania is infected by mild and severe mosaic disease virus, which is transmitted from sap and root, showing vein clearing and reduction of leaflets. The prevalence of infection of mosaic disease virus ranges from 5-20\%. Sesbania plants grown "in vitro" with mild mosaic virus inoculation had fewer pods and were very small in size. The virus inoculated "in vitro" has a great tolerance of dilution (between 1,000-10,000), a resistance to heat $\left(40-60^{\circ} \mathrm{C}\right)$ and has long longevity in vitro varying between 10-14 days and $\left(10-25^{\circ} \mathrm{C}\right)$ (Mall and Kisan, 2003).

Distribution of Sesbania sesban in Africa and in the area of study: Sesbania sp. consists of about 50 species of fast-growing 132 trees, perennial shrubs and herbaceous annuals. Some thirty-three are found in Africa, distributed between central and eastern 
Africa. Sesbania species develop wild in most geographical zones of Africa and in many different soil types (Mohammed Abbas et

al., 2001). Sesbania sesban is the most widely distributed and most important species, with a large number of accessions collected

(Heering, 1995). In Chad, the genus Sesbania sp is represented by many species: Sesbania tchadica A. Chev. (Sesbania sesban

(L.)) (Figure 4), Sesbania microphylla Harms ex Phill \& Hutch, Sesbania leptocarpa D.C., Sesbania pachycarpa D.C., Sesbania pubescens D.C., Sesbania rostrata Brem. \& Oberm., Sesbania sesban (L.) var. nubica, Sesbania sesban subsp. punctata D.C. \& Gillett, Sesbania dalzielii E. Phillips \& Hutch.(Gaston and Fotuis, 1971) (Jean and Cyrille, 2019). Chad is a center of diversity for some of these species. However, Sesbania species have not been fully exploited as multi-purpose plants in many central African countries (Gaston and Fotuis, 1971). Our study shows that the species S. tchadica is abundant in the area that the study was conducted. In the most districts of N'Djamena, we found $S$. tchadica to be the most common type (Figure 3A). It shows a rapid early growth and grows well in different soil types in Chad (Figure 3B). As reported by Jean and Cyrille (2019) and IPNI (2020), Sesbania tchadica (Sesbania sesban) is localized also in Chad in different zones like: riverbanks, stream beds; riparian; water sources of Borkou and Ennedi (Figure 4).
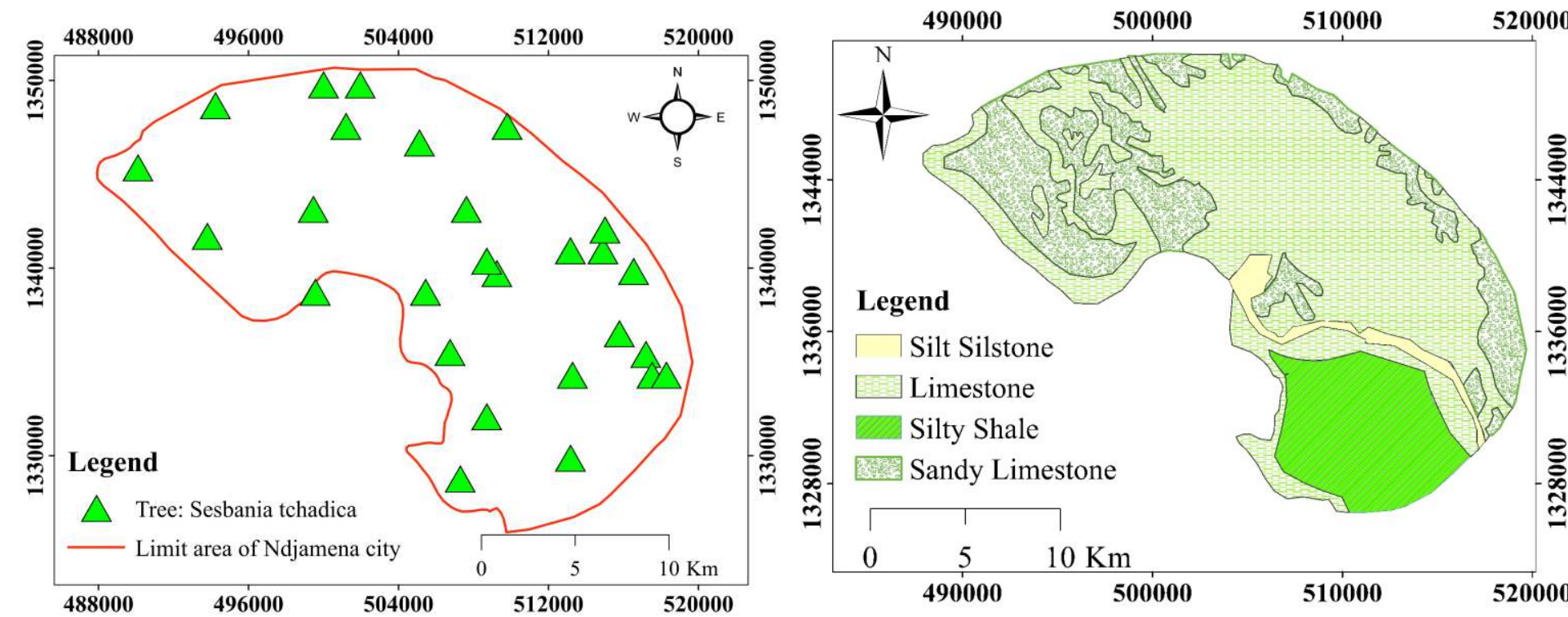

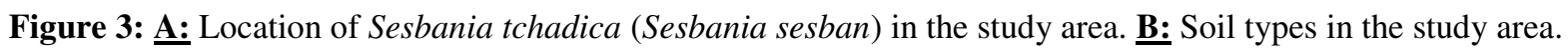



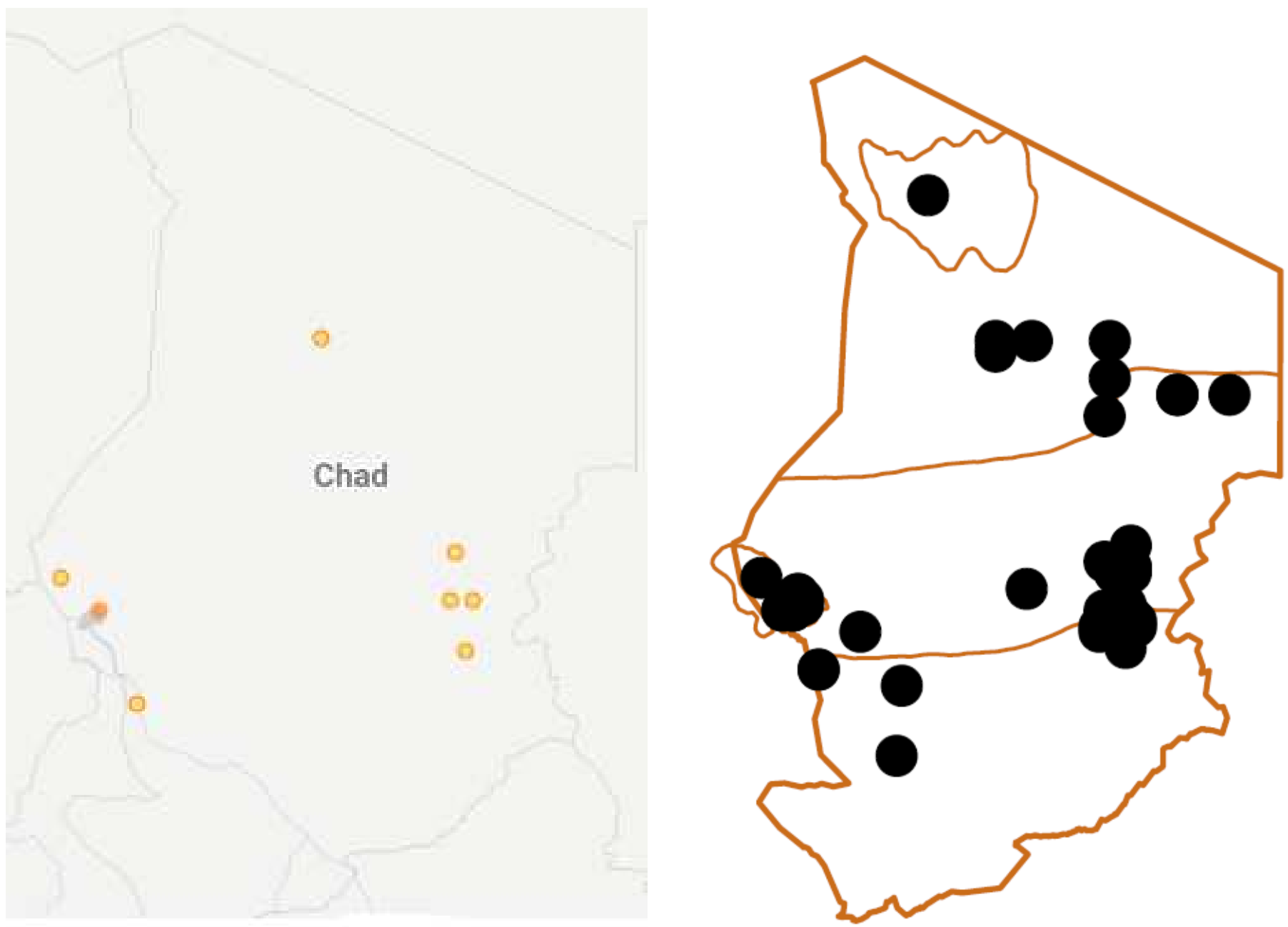

Figures 4: In orange color: Zones of Chad where Sesbania tchadica A. Chev (Sesbania sesban Merr.) is found (IPNI, 2020)

(GBIF, 2020) . In black point: Zones of Chad where Sesbania tchadica (Sesbania sesban) is found (Jean and Cyrille, 2019).

Morphological description: Sesbania tchadica (Sesbania Sesban) has several basal stems that spread with spiked branches (Figure 5A). Its branches are organized with opposite pairs of leaves as a straight line, with points that look like hair. There are at least 20 pairs of leaves that cross one by one each $180^{\circ}$ from the previous, forming a cone that gradually closes(Jean and Cyrille, 2019). These leaves are odd-pinnate with one pair of leaflets at the base with large irregularly-lobed terminal leaflets (Figure 5A). Pods are light green in color just after formation and yellow in color when maturing (Figure 5B). Five to seven pods are grouped together, in grapes form (Figure 5A). Pods and leaves drawing are presented in figure 6C (Jean and Cyrille, 2019). The flowers are yellow and are arranged in clusters forming from two to 20 flowers and almost $20 \mathrm{~cm}$ long (figure 6A). The Filament-sheath is 9$13 \mathrm{~mm}$, the inflorescence is never branched and is yellow speckled with purple or, in rare cases, is pure yellow. The plant glabrescent or glabrous (Figure 5 and figure 6A) (Gillett, 1963) (Ndungu and Boland, 1994) (Jean and Cyrille, 2019). Soaking the seeds in water for a few days is sometimes required to make them germinate (Gillett, 1963). Mani et al., (2011) describe that Sesbania tchadica (Sesbania Sesban) is a short-lived shrub or small tree up to $8 \mathrm{~m}$ tall. Its leaves are pinnately compound, 2-18 cm long with 6-27 pairs of linear oblong leaflets $(26 \times 5 \mathrm{~mm})$. The raceme has 2-20 flowers which are yellow with purple or brown streaks on the corolla. Pods are sub cylindrical, straight or slightly curved up to $30 \mathrm{~cm}$ long and $5 \mathrm{~mm}$ wide containing 10-50 seeds. 163 Five varieties of S. sesban are recognized botanically but their differences do not correlate strongly with their agricultural value 

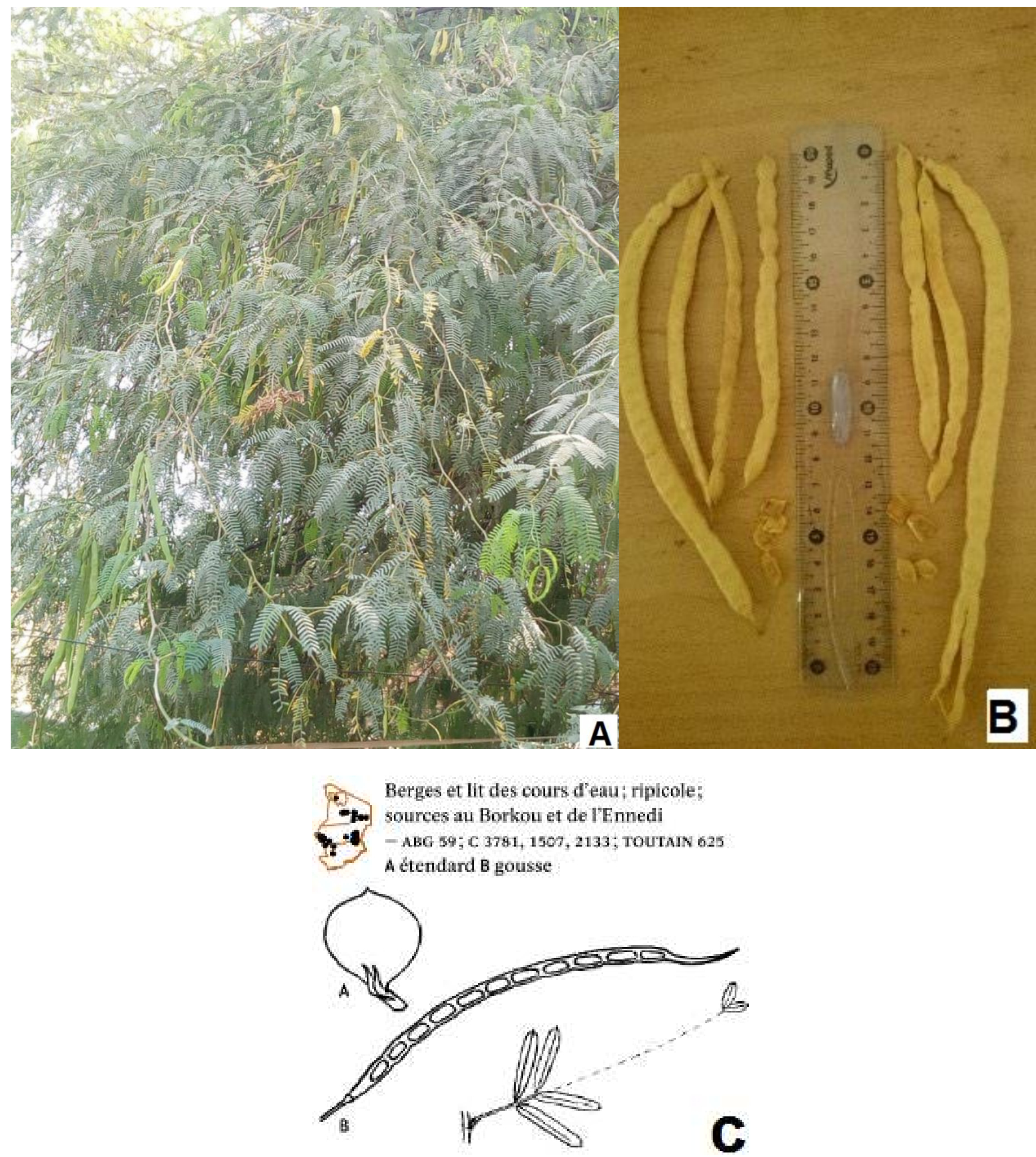

Figures 5: A: Sesbania tchadica (Sesbania Sesban): Tree and branches. (Latitude $12^{\circ} 02^{\prime} 0^{\prime \prime}$ North Longitude $15^{\circ} 12^{\prime}$ East). B: 
We note that the botanical missions carried out on Sesbania tchadica (Sesbania Sesban) date from 1968 by the botanist Léonard,

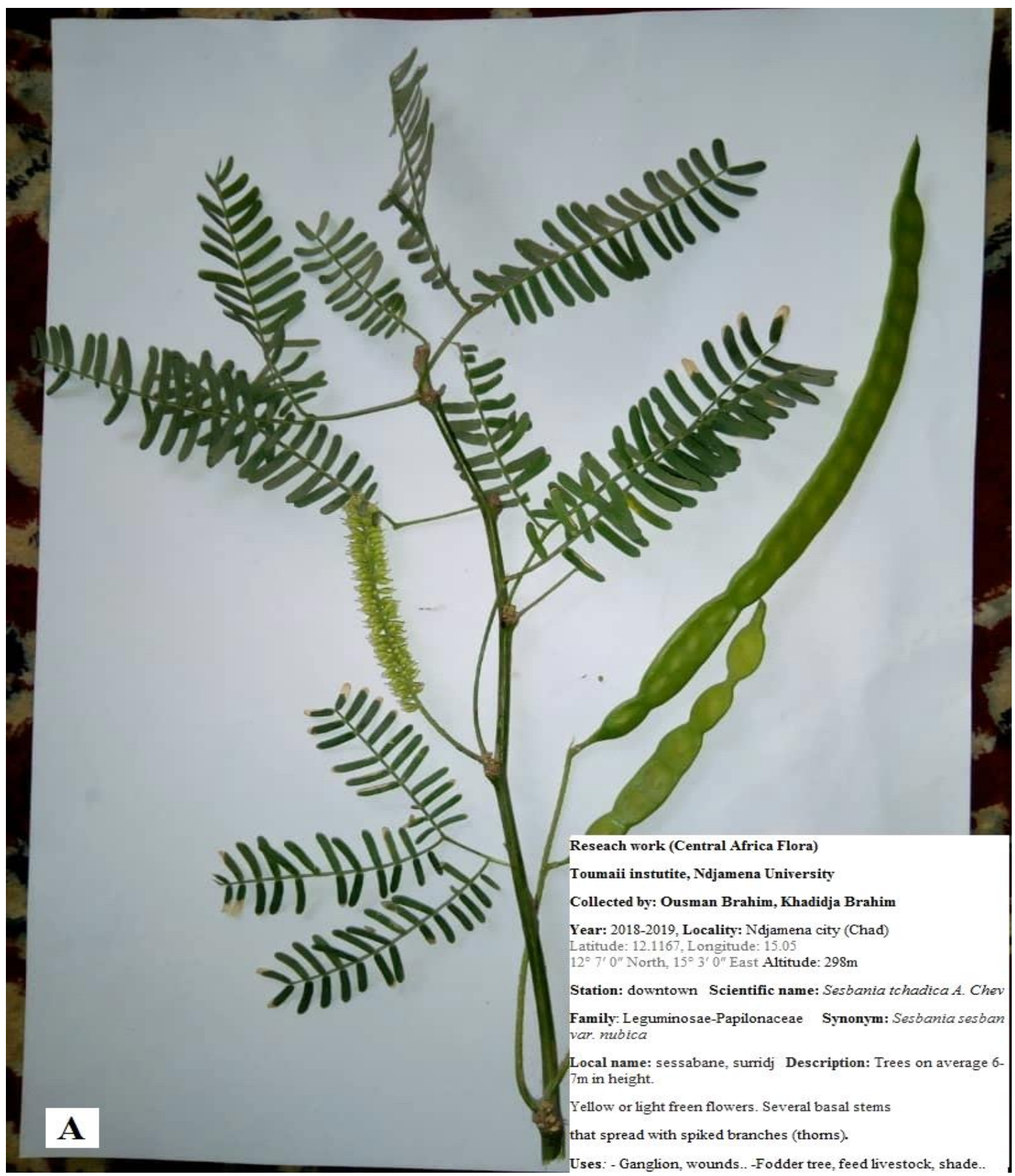




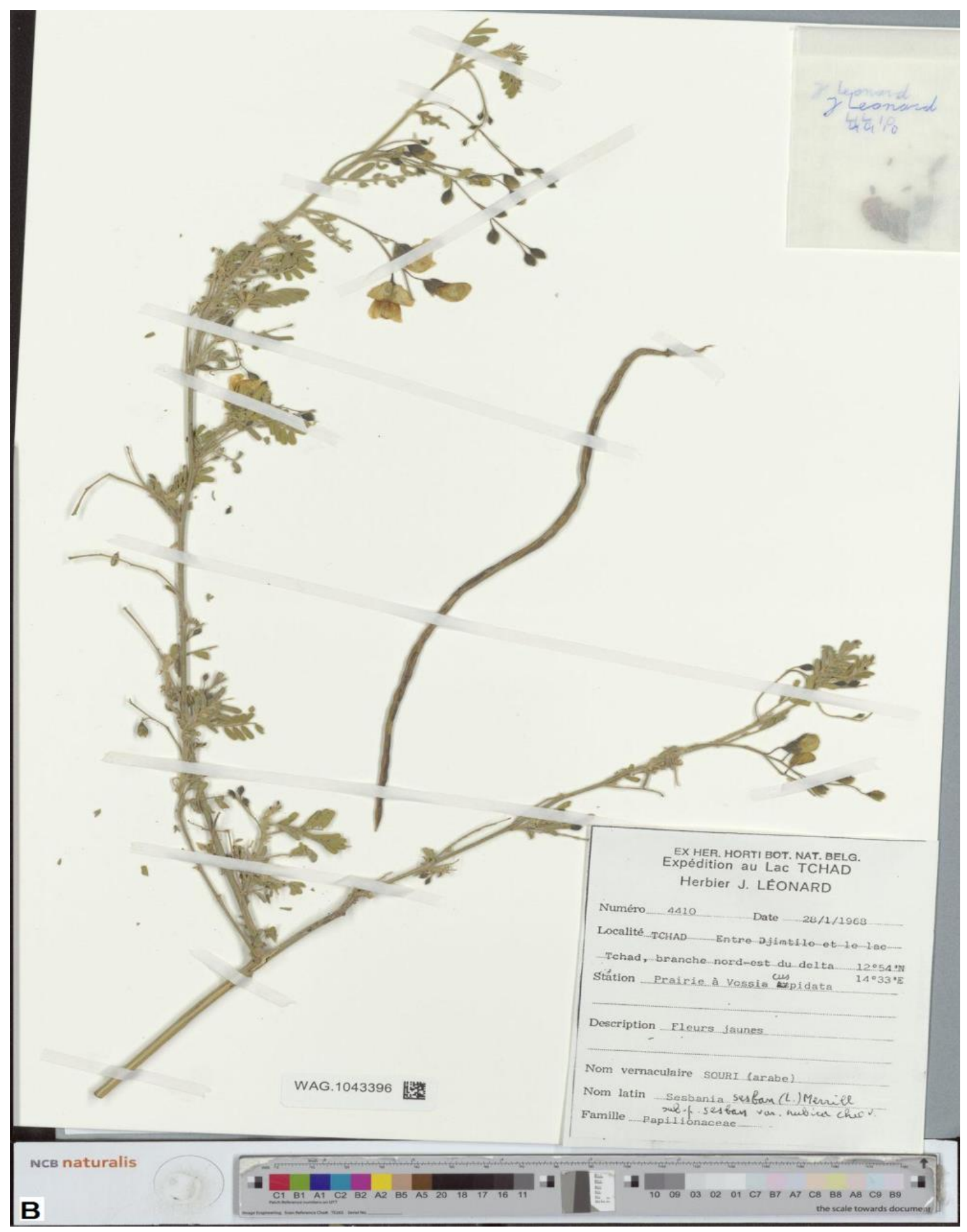

Figures 6: (스) S. tchadica (S. sesban): leaves, flowers, stems, and fresh pods. $(\underline{B})$ :The figure shows the botanical mission carried out on the Sesbania sesban species in Lake Chad area (Léonard, 1968).

Medicinal and other benefits, uses and applications of Sesbania tchadica: Sesbania tchadica (Sesbania sesban) is used as a medicine and as a feed for livestock. Healers in Chad use its leaves and bark alone to treat breast cancer, oedemas and wounds (Ousman et al., 2017) (unpublished). In addition, livestock-keepers cut, carry and feed the leaves to ruminants. The pods are also cut and fed to dairy sheep, goats and oxen. These leaves and pods are considered as a high-protein fodder to increase the milk productivity of these animals (Ousman et al., 2017) (unpublished). Several authors have reported on the medicinal value and ethnobotanical uses of S. tchadica (Moyo et al., 2015). Others reported on the species ecological services such as nodulation, its use in intercropping and in improving fallows (in agriculture), its use as fuelwood (Adelanwa. \& Tijani, 2016), for biomass production 
(Zulfiqar et $a l .$, 2015), and for its ethno-veterinary performance (Frank et al., 2009) (Mohammed et al., 2010). Sontosh et al., (2017) found that the biomass yield of $S$. sesban accessions produced at the earlier growing period is used as green manure crop in shorter fallow period (up to 20 days after sowing DAS) in rotation culture of Rice-Rice-Mustard or other similar cropping patterns. Sesbania sesban produced higher biomass yield at the early growth stages (up to 20 DAS) and its decomposability, organic matter accumulation, and N2-fixing ability may be processed to release as recommended cultivar. S. sesban can be grown in a very short of this rotation culture to maximize organic matter addition to the soil (Sontosh et al., 2017). Details of different uses and applications of Sesbania tchadica (Sesbania Sesban) are shown in Table 2.

Table 2: Results of a review of literature on the uses of Sesbania tchadica (Sesbania sesban)

Different uses of Sesbania tchadica (Sesbania Sesban)

\begin{tabular}{|c|c|c|c|}
\hline \multicolumn{4}{|c|}{ Different uses of Sesbania tchadica (Sesbania Sesban) } \\
\hline Use & Types of use and diseases treated & $\begin{array}{l}\text { Part used and } \\
\text { optimal solvents }\end{array}$ & References \\
\hline \multirow{7}{*}{ Medicinal uses } & Antioxidant activity (saponins and flavonoids, anthocyanins) & $\begin{array}{c}\text { Leaves, seeds } \\
\text { (ethanolic extracts, } \\
\text { methanol) }\end{array}$ & $\begin{array}{c}\text { (Mani et al., 2011) (Kathiresh } \\
\text { et } \text { al., 2012) }\end{array}$ \\
\hline & $\begin{array}{l}\text { Anti-microbial activity (anthocyanins) } \\
\text { Antimicrobial and cytotoxicactivity (carbohydrates, } \\
\text { flavonoids, } \\
\text { steroids, alkaloids, tannins, saponins) }\end{array}$ & $\begin{array}{l}\text { Flower petals } \\
\text { (methanol and } \\
\text { acidified } \\
\text { methanol). } \\
\text { Bark (ethanol, } \\
\text { diethyl ether, } \\
\text { chloroform) }\end{array}$ & $\begin{array}{l}\text { (Kathiresh et al., 2012) } \\
\text { (Arif et al., 2013) }\end{array}$ \\
\hline & Anti-inflammatory activity (crude saponins) & Leaves (methanol) & $\begin{array}{c}\text { (Tatiya et al., 2013) (Shaikh et } \\
\qquad a l ., 2012)\end{array}$ \\
\hline & Anthelmintic activity (saponin glycosides) & $\begin{array}{l}\text { Leaves, seed } \\
\text { (aqueous extracts) }\end{array}$ & (Ibrahim, 1992) \\
\hline & $\begin{array}{l}\text { Antidiabetic activity (Triterpenoids, tannins, saponins, } \\
\text { glycosides, steroids) }\end{array}$ & $\begin{array}{c}\text { Leaves (aqueous } \\
\text { extracts) }\end{array}$ & (Pandhare et al., 2011) \\
\hline & Antinociceptive activity (Sterols, triterpenes flavonoids) & $\begin{array}{l}\text { Wood (petroleum } \\
\text { ether, Chloroform } \\
\text { ethyl acetate) }\end{array}$ & (Nirmal et $a l ., 2012$ ) \\
\hline & $\begin{array}{l}\text { Traditional medicine (in Chad) } \\
\text { (Breast cancer, oedema, swollen glands) }\end{array}$ & $\begin{array}{l}\text { Preparations } \\
\text { method } \\
\text { Breast cancer: } \\
\text {-- Maceration of } \\
\text { leaves for } 48 \text { hours } \\
\text {-- Infusion of root, } \\
\text { bark } \\
\text { Oedema and } \\
\underline{\text { swollen glands: }}\end{array}$ & $\begin{array}{l}\text { (Ousman et } \text { al., 2017) } \\
\text { (unpublished) }\end{array}$ \\
\hline
\end{tabular}




\begin{tabular}{|c|c|c|c|}
\hline \multirow{10}{*}{$\begin{array}{l}\text { Agricultural } \\
\text { uses }\end{array}$} & $\begin{array}{l}\text { days in in waterlogged or drained soils. Sesbania rostrata } \\
\text { compared to Sesbania Sesban, fixes approximately } 110 \mathrm{~kg} \\
\text { of nitrogen per hectare in } 60 \text { days, which places it among the } \\
\text { most powerful fixatives Sesbania species with a higher dry } \\
\text { matter. }\end{array}$ & & \\
\hline & $\begin{array}{l}\text { Sesbania sesban is used as a green manure which increases } \\
\text { the nitrogen on the soil (in crops of rice and wheat) }\end{array}$ & Tree, roots & (Patra et $a l ., 2006)$ \\
\hline & $\begin{array}{l}\text { Rhizobuim strains induce root nodules and fix nitrogen from } \\
\text { the air on the soil in symbiosis with Sesbania sp. } \\
\text { Inducing of root nodules Rhizobuim strains and nitrogen } \\
\text { fixing on the soil in symbiosis with Sesbania sesban }\end{array}$ & $\begin{array}{l}\text { Whole tree } \\
\text { Germinated } \\
\text { seedlings }\end{array}$ & $\begin{array}{c}\text { (Sobere, 1991) } \\
\text { (Bala et al., 2002) } \\
\text { (Sharma et } \text { al., 2005) }\end{array}$ \\
\hline & $\begin{array}{l}\text { Improved fallow systems to enhance agricultural } \\
\text { productivity by increasing the yields of maize and sorghum } \\
\text { by } 1.2-1.8 \mathrm{mg} / \text { hectare and } 0.1-0.7 \mathrm{mg} / \text { hectare, } \\
\text { respectively. Apply about } 7.3 \mathrm{Mg} \text { ha-1 dry matter and } 165 \\
\mathrm{~kg} \mathrm{~N} \text { ha-1 to irrigated wheat and rice. }\end{array}$ & Whole tree & $\begin{array}{l}\text { (Sileshi et } a l ., 2008) \\
\text { (Sileshi et } a l ., 2014)\end{array}$ \\
\hline & $\begin{array}{l}\text { Cultivated in rotation with cotton to enhance nitrogen } \\
\text { fertility and improve soil condition }\end{array}$ & Whole tree & $\begin{array}{c}\text { (Curasson, 1956) (Rochester } \\
\text { et } a l ., 2001)\end{array}$ \\
\hline & $\begin{array}{l}\text { The production of nutrients nitrogen, phosphorus, calcium, } \\
\text { magnesium potassium by foliar biomass }\end{array}$ & $\begin{array}{l}\text { Whole tree } \\
\text { Bark, Stems }\end{array}$ & $\begin{array}{l}\text { (Balaisubramanian \& } \\
\text { Sekayange, 1992) } \\
\text { (Mohammed Abbas et al., } \\
\text { 2001) }\end{array}$ \\
\hline & $\begin{array}{l}\text { Biomass yield of } S \text {. sesban accessions produced is used as } \\
\text { green manure crop in shorter fallow. S. sesban maximizes } \\
\text { organic matter addition to the soil. }\end{array}$ & $\begin{array}{l}\text { Seeds accessions, } \\
\text { Whole tree }\end{array}$ & (Sontosh et $a l ., 2017$ ) \\
\hline & $\begin{array}{l}\text { Intercropping sweetpotato with Sesbania sesban improves } \\
\text { yield of the crop }\end{array}$ & Whole tree & (Muimba-Kankolongo, 2018) \\
\hline & $\begin{array}{l}\text { Intercropping with rice and annual grasses in semi-arid } \\
\text { conditions for managing weeds and optimizing the yield of } \\
\text { dry-seeded rice. } \\
\text { Sesbania, being an aquatic plant, can also be grown together } \\
\text { with rice to suppress weeds }\end{array}$ & $\begin{array}{l}\text { Whole tree } \\
\text { Bark }\end{array}$ & $\begin{array}{l}\text { (Mohammed Abbas et al., } \\
\text { 2001) } \\
\text { (Singh et al., 2007) }\end{array}$ \\
\hline & Improved fallows and as herbaceous cover crops & Whole tree & $\begin{array}{l}\text { (Dagar and Tewari, 2017) } \\
\text { (Nair, 1993) }\end{array}$ \\
\hline & $\begin{array}{l}\text { If used as a supplement, it may improve the cow's health } \\
\text { and shorten the calving interval. }\end{array}$ & Leave meal & $\begin{array}{l}\text { (Roothaert \& Paterson, 1997) } \\
\text { (Frank et al., 2009) }\end{array}$ \\
\hline & $\begin{array}{l}\text { Improving the traditional sheep husbandry: Increased milk } \\
\text { and meat production }\end{array}$ & $\begin{array}{l}\text { Leave and young } \\
\text { twigs. } \\
\text { Whole tree }\end{array}$ & $\begin{array}{l}\text { (Mekoya et } a l ., 2009) \\
\text { (Franzel et } a l ., 2014)\end{array}$ \\
\hline & Improve smallholder's livestock productivity, source of & Whole tree & (Franzel et al., 2014) \\
\hline
\end{tabular}




\begin{tabular}{|c|c|c|c|}
\hline \multirow{10}{*}{$\begin{array}{c}\text { Other } \\
\text { applications }\end{array}$} & $\begin{array}{l}\text { revenue, and livelihoods. Fodder, feed livestock tree for } \\
\text { dairy goats, sheep, and cows (small ruminants). }\end{array}$ & & \\
\hline & $\begin{array}{l}\text { Vegetation covers in desert areas. Fodder for livestock } \\
\text { (goats, sheep). Increasing the fertility and productivity of } \\
\text { sandy soil in the desert area }\end{array}$ & Whole tree & $\begin{array}{c}\text { (Ousman et al., 2017) } \\
\quad \text { (unpublished) } \\
\text { (Curasson, 1956) (Mohammed } \\
\text { Abbas et al., 2001) }\end{array}$ \\
\hline & Restore eroded soil by fixing N2 & Whole tree & $\begin{array}{c}\text { (Degefu et al., 2011) } \\
\text { (Nigussie \& Getachew, 2013) }\end{array}$ \\
\hline & Sesbania sesban is used as hedge & Whole tree & (Curasson, 1956) \\
\hline & $\begin{array}{l}\text { Sesbania sesban is developed for its wind shade. Sesbania } \\
\text { sesban is used as windbreaks, as cover crops, ornamental } \\
\text { plants, and as fish poisons for light sticks, used in building } \\
\text { huts, making charcoal, preparing gunpowder. }\end{array}$ & Whole tree & $\begin{array}{l}\text { (Samajdar \& Ghosh, 2017) } \\
\text { (Gillett, 1963) }\end{array}$ \\
\hline & $\begin{array}{l}\text { The biomass of Sesbania sesban can produce wood within } \\
\text { just 3-6 months when it grows with Cajanus cajan } \\
\text { (leguminous) and used so as cooking fuel }\end{array}$ & Whole tree & (Adelanwa \& Tijani, 2016) \\
\hline & $\begin{array}{l}\text { Sesbania sesban is used in many African countries as a good } \\
\text { source of fuel, grows fast, burns well, can be coppiced. It is } \\
\text { used as fiber for ropes and fishing nets, and the seeds } \\
\text { produce a gum. }\end{array}$ & $\begin{array}{l}\text { Stem and thick } \\
\text { branches } \\
\text { Bark }\end{array}$ & $\begin{array}{l}\text { (World Agroforestry Centre, } \\
\text { 2002) }\end{array}$ \\
\hline & $\begin{array}{l}\text { Sesbania grows in the salt-affected soils and limits the effect } \\
\text { of salinity. Inoculating of Sesbania sesban with salinity- } \\
\text { tolerant rhizobia under saline conditions increases biological } \\
\text { nitrogen fixation }\end{array}$ & Whole tree & $\begin{array}{l}\text { (Bakhoum et } a l ., \text { 2018) (Bala } \\
\text { et } a l ., \text { 1990) }\end{array}$ \\
\hline & $\begin{array}{l}\text { Soil treatment laden with heavy metals } \\
\text { Potential for use in treatment systems of waste or polluted } \\
\text { water }\end{array}$ & Whole tree & $\begin{array}{l}\text { (Gupta et al., 2011) (Dan and } \\
\text { Hans, 2009) } \\
\text { (Dan et } \text { al., 2011) }\end{array}$ \\
\hline & $\begin{array}{l}\text { Green manure plants as Sesbania sp. combined with sewage } \\
\text { sludge are an initial fertility driver for rapid increasing yield } \\
\text { of maize, decreased salinity and } \mathrm{pH} \text {, and increased organic } \\
\text { carbon, nitrogen and phosphor concentrations in mudflat } \\
\text { soil. }\end{array}$ & Whole tree & (Bai et $a l ., 2017$ ) \\
\hline
\end{tabular}

Phytochemical compounds of Sesbania tchadica (Sesbania sesban): Sesbania tchadica (Sesbania sesban) has different chemical 200 compounds that are, once extracted, very useful for treating diseases, manufacturing of drugs, organic or chemical supplements and 201 antibacterial or antioxidant agents, manufacturing of biological manure, among others (Patra et al., 2006) ; (Kathiresh et al., 2012) (table 202 1). Details of phytochemicals compound combined with different extraction solvents are shown in Table 3.

Table 3: Sesbania tchadica (Sesbania sesban): Different Phytochemical compounds with the parts used and their extracts solvent.

\begin{tabular}{|l|l|l}
\hline Phytochemicals compounds and parts used of Sesbania tchadica & Solvents Extracts & References
\end{tabular}


Page $\mathbf{1 5}$ of $\mathbf{2 5}$

\begin{tabular}{|l|l|c|}
\hline \multicolumn{1}{|c|}{ (Sesbania sesban) } & & \\
\hline $\begin{array}{l}\text { Sterols, saponins, flavonoids } \\
\text { Sterols, alkaloids. Fats and oil. Proteins, sterols, saponins, flavonoids, } \\
\text { glycoside, vitamins sesbanins, sesbanimid phosphorus (Leaves). }\end{array}$ & $\begin{array}{l}\text { Methanol, Chloroform, } \\
\text { Petroleum ether 60-80 }\end{array}$ & (Shaikh et al., 2012) \\
\hline $\begin{array}{l}\text { Campesterol, beta-sitosterol. (Pods, leaves). Cyanidin, delphinidin } \\
\text { glucosides (Flowers). }\end{array}$ & Aqueous extracts & (Khare, 2007) \\
\hline $\begin{array}{l}\text { Triterpenoids, carbohydrates, vitamins, amino acids, proteins, tannins, } \\
\text { saponin glycosides steroids (Leaves, seed) }\end{array}$ & Aqueous extracts & (Ibrahim, 1992) \\
\hline $\begin{array}{l}\text { Phenolics, anthocyanins, flavonoids (Flowers) } \\
\text { Steroids, Alkaloids. Reducing Sugars (carbohydrates), Tannins, } \\
\text { Flavonoids, Saponin (Bark) }\end{array}$ & Methanol 2011) & (Kathiresh M. et al., \\
\hline Cholesterol, campesterol and beta-sitosterol (Pods) & (95\% each one) & (Arif et al., 2013) \\
\hline $\begin{array}{l}\text { Alpha-ketoglutaric, oxaloacetic and pyruvic acids (Pollen and pollen } \\
\text { tubes) }\end{array}$ & - & (Goswami et $a l ., 2016)$ \\
\hline Crude protein and crude fiber (Dry matter of leaf) & - & (Khare, 2007) \\
\hline Sterols, triterpenes. Flavonoids (Wood) & - & (Khare, 2007) \\
\hline
\end{tabular}

\section{3- Discussion}

Sesbania tchadica is a leguminous tree native to Chad that is used to increase crop yields and vegetation in some desert areas. The local 208 population and particularly pastoralists plant it in arid zones to increase the plant cover, to obtain shade for humans and their animals and 209 to use its wood for construction. The local population also uses Sesbania tchadica to enrich soil fertility for increasing yields of crops such as rice, maize and sorghum and to repel desert encroachment in zones with little vegetation (Ousman et al., 2017) (unpublished). The author (Bashan et al., 2012) have demonstrated that native leguminous trees such as Sesbania tchadica are essential to ensure the revegetation of eroded desert lands and to restore eroded soil. These authors have also inoculated these leguminous trees with Plant Growth-Promoting Bacteria (PGPB) in agricultural and agroforestry systems. They planted a high density of these leguminous trees in certain areas with severely eroded soil and the result was a remarkable degree of revegetation and more stabilized soils. Sesbania tchadica can play an important role, along with other leguminous species, in land restoration and the protection and conservation of indigenous species in Chad (FAO, 2012).

In the present study, the authors found that most populations of Sesbania tchadica in N'Djamena are planted by the local population whereas in areas surrounding the city, most are wild (Jean and Cyrille, 2019). This suggests that the local population is aware of the importance of the species and wishes to benefit from its fast growth and its use for fuelwood, for improving soil fertility and for feeding and shading livestock. it measures approximately 4-5 meters in height.in six months with a diameter of up to $12 \mathrm{~cm}$ (Shun-ching, 1960), 
Recherche Agronomique INRA has become interested in the adaptation of certain crops to saline environments and their contribution to improving food and fodder production in desert or arid areas. Successful results of resilient cultures and cover vegetation are obtained by

However, some important problems exist which threaten Sesbania tchadica and other leguminous trees in Chad. Robert \& Mahamat Ali, 230 (2005) pointed out that around cities such as Ndjamena; the high demand for fuelwood threatens the sustainability of supply. Nwilo et al., (2020) noted that vegetation in the northwest and the northeast of Nigeria including the region of Lake Chad declined by $2.18 \%$ from 1984 to 2000 and by 2.02\% from 2000-2016. The causes included agricultural activities such as extensive grazing, and annual cropping, other uses of the trees such as for fuelwood, charcoal, panelling and woodwork and variations in climate (Nwilo et al., 2020). Such exploitation poses risks to the conservation of the whole flora in these and other tropical and sub-tropical regions (Rukangira Ernest, 2001), (Ribeiro et al., 2017). Rukangira (2001) noted that policy makers, other stakeholders and citizens need to support conservation and help increase awareness of the problem.. Moreover, effective strategies for biodiversity conservation should focus on regions with rare and endangered species, on locally abundant species that are functionally vital in maintaining the plant community and on regions with considerable heterogeneity of vegetation (Ribeiro et al., 2017). The collection of the plant material and the documentation, botanical identification and preparation of the herbarium vouchers are tasks that cannot be automated and thus require specialists who are becoming increasingly rare (Bucar et al., 2013); (Bruno et al., 2015).

In the current study, the species Sesbania tchadica was collected using standard procedures by Chadian expert foresters and botanists from the Toumaï Institute and LRID Herbaria. Next, to identify the plant material, the authors used the empirical keys determination (leaves and pods forms, plant size, etc.). This determination is based on previous work of the botanist Léonard (Léonard, 1968) who did a collection of this species in the region of Lake Chad as part of a Belgian botanical expedition. This study also uses the plant illustrations of Sesbania sesban and Sesbania tchadica done by botanists Jean César and Cyrille Chatelain in their study of the Chadian flora (Jean and Cyrille, 2019). Jean and Cyrille (2019) explain that botanists who conduct research in Africa rarely have the opportunity to study the DNA of the plants they work on. For this reason, in the current study (as the Léonard and Jean \& Cyrille studies), we have used the classical determination keys of Sesbania tchadica, (as cited above). This allows a more logical hierarchy of groups based on morphological characters, which are really the only ones accessible to the field botanist.

\section{4- Conclusion}

The ethnobotanical study carried out specifically from Ndjamena region and its surroundings allowed the authors to assess at the local level an important tree and shrub species, Sesbania tchadica (Sesbania Sesban). Sesbania tchadica leaves were harvested and organized according to a morphological model in order to facilitate its identification. However, this morphological and descriptive study conducted on Sesbania tchadica proved to be very complex because the exploitation of data at local level still less-exploited. As a result, this paper contributes to the production and maintenance of a new database on this species. It is also a gain for the scientific world and the research organizations in Chad and internationally. This study will hopefully contribute to the protection, use and value of Sesbania tchadica.

Acknowledgments: The authors present their deep gratitude to the management team of the National Federation Associations Healers Modou Abderramane and his collaborators. The authors also thank Health-Biotechnologies, Geology \& Oceanology, and Toumaï Institute laboratories for their assistance in data and software. The authors gratefully acknowledge Professor Ibrahima Ndoye (from 
Cheikh Anta Diop University of Dakar, Senegal, Faculty of Sciences and Techniques/Department of Plant Biology) for his reviewing 263 and assessment of this paper. Our gratitude thanks go also to all those who accompanied us during the field work in N'Djamena and its surroundings.

Declarations

Ethics approval and consent to participate: The manuscript is not submitted to other journal for simultaneous consideration. The work is original and

\section{Compliance with ethical standards}

Competing interests: The authors have no relevant financial or non-financial interests to disclose.

Funding: The authors did not receive support from any organization for the submitted work.

Availability of data and materials: The data that support the findings of this study are available from the corresponding author upon reasonable request. All data relating to this species generated during the study survey are included in this paper. A voucher specimen is deposited of the Toumaï Institute and IRED herbaria (Chad) and then in the Applied Biology and Pathology Laboratory Herbarium (Morocco).

Authors' contribution statements: O. B. M.: Conceptualization, Methodology, Data, Writing, and Investigation. S. Y., B. B. O. and

S. F.: Supervision, Writing, Reviewing, Investigation. A. O. M. Software, Data. A. F. and the other authors: Visualization,

References:

Abdel Magid H. M., Singleton, P. W., \& Tavares, J. W. (1988). Sesbania-Rhizobium Specificity and Nitrogen Fixation. Desert

Adelanwa E. B., \& Tijani M. O. (2016). Performance of Cajanus cajan [1.] millsp. and Sesbania sesban as cooking fuel. Journal of

Anon 1992. Annual Report 1991, \& International Centre for Research in Agroforestry ICRAF. Nairobi. (1992). In: Ndungu J. N. and

Boland D. J. (1994). Sesbania seed collections in Southern Africa. Developing a model for collaboration between a CGIAR Centre and NARS.

Anonymous. (1985). Sesbania sesban (L.) Merr. Sesbania grandiflora (L.) Pers.

Arif Ahmed, Labu, Z., Dey, S., Hira, A., Howlader, M. I., Hossain, M., \& Roy, J. (2013). Phytochemical screening, antimicrobial and cytotoxic activity of different fractions of Sesbania sesban bark. International Journal of Basic Medical Sciences and Pharmacy, 5(4), 206. https://doi.org/10.4103/1947-489x.210546

Auguste Chevalier. (1913). Etudes sur la flore de l'Afrique centrale française (Bassins de l'Oubangui et du Chari) Tome I. Enumération des plantes récoltées. Université de Cornell and Paris, A. Challamel, Mission Chari-Lac Tchad. 
Bai Yanchao, Zang, C., Gu, M., Gu, C., Shao, H., Guan, Y., Wang, X., Zhou, X., Shan, Y., \& Feng, K. (2017). Sewage sludge as an initial fertility driver for rapid improvement of mudflat salt-soils. Science of the Total Environment, 578, 47-55. https://doi.org/10.1016/j.scitotenv.2016.06.083

Baker J. G. (1926). The Leguminosae of Tropical Africa (1926).): Base de données des plantes d'Afrique: Sesbania tchadica A. Chev.

Conservatoire et Jardin Botaniques \& South African National Biodiversity Institute. http://www.villege.ch/musinfo/bd/cjb/africa/details.php?langue=fr\&id=127976

Bakhoum N., Fall, D., Fall, F., Diouf, F., Hirsch, A. M., Balachandar, D., \& Diouf, D. (2018). Senegalia senegal (synonym : Acacia

Bala Abdullahi, Murphy Phillip, \& Giller Ken E. (2002). Occurrence and genetic diversity of rhizobia nodulating Sesbania sesban in

Bala Neeru, Sharma P. K., \& Lakshminarayana K. (1990). Nodulation and nitrogen fixation by salinity-tolerant rhizobia in symbiosis with tree legumes. Agriculture, Ecosystems and Environment, 33(1), 33-46. https://doi.org/10.1016/0167-8809(90)90142-Z

Balaisubramanian V., \& Sekayange L. (1992). Effets de la culture en couloirs sur les propriétés du sol et les performances des arbustes et des cultures vivrières dans un environnement semi-aride au Rwanda. International Rice Research Institute, 180-190. https://www.researchgate.net/publication/32976933

Bashan Y., Salazar, B. G., Moreno, M., Lopez, B. R., \& Linderman, R. G. (2012). Restoration of eroded soil in the Sonoran Desert with native leguminous trees using plant growth-promoting microorganisms and limited amounts of compost and water. Journal of Environmental Management, 102, 26-36. https://doi.org/10.1016/j.jenvman.2011.12.032

Bindraban S Prem, van der Velde, M., Ye, L., van den Berg, M., Materechera, S., Kiba, D. I., Tamene, L., Ragnarsdóttir, K. V., Jongschaap, R., Hoogmoed, M., Hoogmoed, W., van Beek, C., \& van Lynden, G. (2012). Assessing the impact of soil degradation on food production. Current Opinion in Environmental Sustainability, 4(5), 478-488. https://doi.org/10.1016/j.cosust.2012.09.015

Bradbury M. (1990). The effect of water stress on growth and dry matter distribution in juvenile Sesbania sesban and Acacia nilotica. Journal of Arid Environments, 18(3), 325-333. https://doi.org/10.1016/s0140-1963(18)30842-5

Bruno David, Jean Luc Wolfender, \& Daniel A. Dias. (2015). The pharmaceutical industry and natural products: historical status and new trends. Phytochemistry Reviews, 14(2), 299-315. https://doi.org/10.1007/s11101-014-9367-z

Bucar F., Wube, A., \& Schmid, M. (2013). Natural product isolation-how to get from biological material to pure compounds. Natural Product Reports, 30(4), 525-545. https://doi.org/10.1039/c3np20106f

Chinsembu Kazhila C. (2015). Plants as antimalarial agents in Sub-Saharan Africa. Acta Tropica, 152, 32-48. 
médecine vétérinaire des pays tropicaux, p. 49-84, 1956.

https://www.researchgate.net/publication/318309602_Etudes_sur_les_paturages_tropicaux_et_subtropicaux_plantes_apparte

Dagar J. C. and Tewari V. P. (2017). Agroforestry: Anecdotal to Modern Science. In Agroforestry. Springer Nature Singapore Pte Ltd.

p. 869. https://doi.org/10.1007/978-981-10-7650-3

Dakora F. D. and Keya S. 0. (1997). Contribution of legume nitrogen fixation to sustainable agriculture in sub-saharan Africa. Soil Biology and Biochemistry, 29(5-6), 809-817. https://doi.org/10.1016/S0038-0717(96)00225-8

Dan Truong Hoang and Hans Brix. (2009). Growth responses of the perennial legume Sesbania sesban to NH 4 and NO 3 nutrition and effects on root nodulation. Aquatic Botany, 91(3), 238-244. https://doi.org/10.1016/j.aquabot.2009.07.004

Dan Truong Hoang, Le Nhat Quang, Nguyen Huu, \& Hans Brix. (2011). Treatment of high-strength wastewater in tropical constructed wetlands planted with Sesbania sesban: Horizontal subsurface flow versus vertical downflow. Ecological Engineering, 37(5), 711-720. https://doi.org/10.1016/j.ecoleng.2010.07.030

Degefu Tulu, Wolde-meskel, E., \& Frostegård, Å. (2011). Multilocus sequence analyses reveal several unnamed Mesorhizobium genospecies nodulating Acacia species and Sesbania sesban trees in Southern regions of Ethiopia. Systematic and Applied Microbiology, 34(3), 216-226. https://doi.org/10.1016/j.syapm.2010.09.006

DeRouw A. (1998). Gestion de la fertilité du sol sur un terroir sahélien. Fumure animale, matière organique et encroûtement superficiel du sol dans les systèmes de culture de mil, étude au Niger. Soil fertility management in the Sahel. Manure, organic matter and crust form. Agriculture et Développement CIRAD, 18, 63-70. https://agritrop.cirad.fr/400925/1/document_400925.pdf

Dreyfus B. L., \& Dommergues Y.R. (1981). Nitrogen-fixing nodules induced by rhizobium on the stem of the tropical legume Sesbania rostrata. FEMS Microbiology Letters, 10(4), 313-317. https://www.sciencedirect.com/science/article/abs/pii/0378109781901166

FAO Food and Agriculture Organisation. (2012). Synthèse des études thématiques sur la foresterie urbaine et périurbaine de http://www.fao.org/3/i2850fwp7/i2850fwp7.pdf

Frank Place, Roothaert, R., Lucy, M., Judith, S., Franzel, S., \& Wanjiku, J. (2009). The impact of fodder trees on milk production and income among smallholder dairy farmers in East Africa and the role of research (P. Fredenburg (ed.)). p. 47. Nairobi, Kenya. https://www.academia.edu/download/53084101/The_impact_of_fodder_trees_on_milk_produ20170511-3627-m2wjsk.pdf

Franzel S., Carsan, S., Lukuyu, B., Sinja, J., \& Wambugu, C. (2014). Fodder trees for improving livestock productivity and smallholder livelihoods in Africa. Current Opinion in Environmental Sustainability, 6(1), 98-103.

Gaston André and Fotuis Georges. (1971). Lexique de noms vernaculaires de plantes du Tchad. p. 355. Laboratoire de Farcha, FortLamy NDjamena,Tchad. http://horizon.documentation.ird.fr/exl-doc/pleins_textes/divers11-05/05320.pdf 
https://books.google.co.ma/books?id=NgK1616nboUC\&dq=sesbania+sesban+grows+in+savannah\&hl=fr\&so

Gillett J. B. (1963). Sesbania in Africa (Excluding Madagascar) and Southern Arabia. Plants People Possibilities Springer on Behalf of Royal Botanic Gardens, Kew, 17(1), 91-159. http://www.jstor.org/stable/4118710

Global Biodiversity Information Facility GBIF. (2020). Sesbania sesban (L) Merr . Chad. FLOTROP, a Massive Contribution to Plant 368 Diversity Data for Open Ecosystems in Tropical Africa. Published by CIRAD SELMET. https://www.gbif.org/occurrence/map?country=TD\&has_coordinate=true\&has_geospatial_issue=false \&taxon_key=2970648

Goswami, S., Mishra, K., Singh, R. P., \& Singh, P. (2016). Sesbania sesban, A Plant with Diverse Therapeutic Benefits : An Overview. Journal of Pharmaceutical Research \& Education, 1(1), 111-112. https://www.researchgate.net/publication/307601150\%0ASesbania

Gupta Amit K., Su, S. W., \& Chen, Z. S. (2011). Heavy-Metal bioavailability and Chelate mobilization efficiency in an assisted 374 phytoextraction process by Sesbania sesban (L.) Merr. Communications in Soil Science and Plant Analysis, 42(2), 231-245. https://doi.org/10.1080/00103624.2011.535073

Harun-or-Rashid Mohammed, Tanzin, R., Ghosh, K. C., Jahan, R., Khatun, M. A., \& Rahmatullah, M. (2010). An ethnoveterinary survey of medicinal plants used to treat cattle diseases in Birishiri area, Netrakona district, Bangladesh. Advances in Natural and Applied Sciences, 4(1), 10-13. https://www.researchgate.net/publication/289176508_An_ethnoveterinary_survey_of_medicinal_plants_used_to_treat_cattle 380 _diseases_in_Birishiri_area_Netrakona_district_Bangladesh

Heering J. H. (1995). Botanical and agronomic evaluation of a collection of Sesbania sesban and related perennial species [Thesis, p. 124. Wageningen Agricultural University, Wageningen, The Netherlands.]. https://library.wur.nl/WebQuery/wurpubs/29941

Heuzé V., Tran G., \& Bastianelli D. (2016). Sesban (Sesbania Sesban). Feedipedia, a Programme by INRA, CIRAD, AFZ and FAO. https://www.feedipedia.org/node/253

Ibrahim A. M. (1992). Anthelmintic Activity of some Sudanese Medicinal Plants. Phytotherapy Research, 6, $155-157$. https://doi.org/10.1002/ptr.2650060312

INRA Institut National de la Recherche Agronomique National Institute of Agronomic Research. (2019). Maroc : Premier Forum international sur 1 'agriculture biosaline à Laâyoune. Des exemples réussis de cultures résilientes en milieu salin. Institut National de La Recherche Agronomique INRA, Maroc. https://www.inra.org.ma/fr/content/05052019-des-exemples-réussisde-cultures- résilientes-en-milieu-salin-à-foum-el-oued. http://agripeche.com/4239-maroc- premier-forum-international-surlagriculture-biosaline-a-laayoune.html

IPNI International Plant Names Index. (2020). Sesbania tchadica A.Chev. International Plant Names Index Collaborators (2019). Checklist Dataset. https://www.ipni.org/n/urn:lsid:ipni.org:names:518546-1 
édition avec l'Université de N'Djaména et la Coopération Suisse au Tchad, p. 387.

https://www.researchgate.net/publication/334113080_Flore_illustree_du_Tchad.

https://www.researchgate.net/publication/334113080_Flore_illustree_du_Tchad

Kaitho, R. J. (1997). Nutritive value of browses as protein supplement to poor quality roughages [Thesis, p. 196. Landbouw

Kathiresh M., Devi, P. S., \& M.Saravanakumar. (2012). Bioactive compounds in Sesbania sesban flower and its antioxidant and

Khare C. P. (2007). Indian Medicinal Plants:An Illustrated Dictionary. p. 900. Springer-Verlag New York.

Kiptot Evelyne, Franzel, S., \& Degrande, A. (2014). Gender, agroforestry and food security in Africa. Current Opinion in

Kwesiga F. R., Franzel, S., Place, F., Phiri, D., \& Simwanza, C. P. (1999). Sesbania sesban improved fallows in eastern Zambia: Their

Lahdachi F. Z., N., L., Jamal I., And, \& Faouzia M. (2015). Aperçu sur les Acacias spontanés et introduits au Maroc. European

Léonard Joseph Jean. (1968). Expédition au Lac Tchad : Expédition nationale belge Horti-Botanique au Tchad (entre Djimtilo et le Lac Tchad), branche nord-est du delta.

Li, L., Yang, T., Liu, R., Redden, B., Maalouf, F., \& Zong, X. (2017). Food legume production in China. Crop Journal, 5(2), 115126. https://doi.org/10.1016/j.cj.2016.06.001

Mall T. P. and Kisan P. G. (2003). Virus diseases of dhaincha Sesbania aculeata Pers. Journal Liv- World India, 10(2), 16-19. https://www.researchgate.net/publication/327466758\%0AVirus

Mani R.P., Awanish, P., Shambaditya, G., Poonam, T., Kumudhavalli, V., \& Ajay Pratap, S. (2011). Phytochemical Screening and Invitro Evaluation of Antioxidant Activity and Antimicrobial Activity of the Leaves of Sesbania sesban (L) Merr. Free Radicals and Antioxidants, 1(3), 66-69. https://doi.org/10.5530/ax.2011.3.9

Maria Vittoria Conti, Guzzetti, L., Panzeri, D., De Giuseppe, R., Coccetti, P., Labra, M., \& Cena, H. (2021). Bioactive compounds in legumes: Implications for sustainable nutrition and health in the elderly population. Trends in Food Science and Technology. https://doi.org/10.1016/j.tifs.2021.02.072

Mekoya A., Oosting, S. J., Fernandez-Rivera, S., Tamminga, S., \& Van der Zijpp, A. J. (2009). Effect of supplementation of Sesbania sesban to lactating ewes on milk yield and growth rate of lambs. Livestock Science, 121(1), 126-131. 
Mmoudiongh A., \& Rinaudoe, G. (1985). Fixation d'azote par Sesbania rostrata: son utilisation comme engrais vert. Bulletin de Recherche Agronomique. Gembloux, 20(3/4), 833-849. http://horizon.documentation.ird.fr/exldoc/pleins_textes/pleins_textes_7/b_fdi_59-60/010026661.pdf

Mohammed Abbas, Monib, M., Rammah, A., Fayez, M., \& Hegazi, N. (2001). Intercropping of sesbania (Sesbania sesban) and leucaena (Leucaena leucocephala) with five annual grasses under semi-arid conditions as affected by inoculation with specific rhizobia and associative diazotrophs. Agronomie, 21(6-7), 517-525. https://doi.org/10.1051/agro:2001141

Mohammed Rahmatullah, Mollik, M. A. H., Alam, M. J., Ahmmed, B., Jahan, F. I., Mariz, S., Himel Nahreen Khaleque, Majeedul H. Chowdhury, F. A. N., Rahman, S., Jahan, R., \& Sera, S. (2010). An Ethnoveterinary Survey of Medicinal Plants Used by Folk Medicinal Practitioners to Treat Cattle Diseases in Randomly Selected Areas of Bagerhat District, Bangladesh. American-Eurasian Journal of Sustainable Agriculture, C(C), CC-CC. https://www.academia.edu/5776667/An_Ethnoveterinary_Survey_of_Medicinal_Plan_ts_Used_by_Folk_Medicinal_Practiti oners_to_Treat_Cattle_Diseases_in_Randomly_Select_ed_Areas_of_Bagerhat_District_Bangladesh

Moyo MacK, Aremu, A. O., \& Van Staden, J. (2015). Medicinal plants: An invaluable, dwindling resource in sub-Saharan Africa. Journal of Ethnopharmacology, 174, 595-606. https://doi.org/10.1016/j.jep.2015.04.034

Muimba-Kankolongo, A. (2018). Root and Tuber Crops. In Food Crop Production by Smallholder Farmers in Southern Africa (pp. 123-172). Academic Press. https://doi.org/10.1016/b978-0-12-814383-4.00009-8

Naik N. N., Tare H. L., Sherikar A .K., Deore S.R., \& Dama G.Y. (2011). Central Nervous System Stimulant Effect of Extracts Obtained From the Barks of Sesbania Sesban. International Journal of Institutional Pharmacy and Life Sciences, 1(1), 7792. http://www.ijipls.com/uploaded/journal_files/110715110700.pdf

Nair Ramachandran P.K. (1993). An Introduction to Agroforestry. p. 489. Kluwer Academic Publishers, Dordrecht, The Netherlands. https://doi.org/10.1177/003072709402300413

Ndoye I., \& Dreyfus B. (1988). N2 fixation by Sesbania rostrata and Sesbania sesban estimated using $15 \mathrm{~N}$ and total N difference methods. Soil Biology and Biochemistry, 20(2), 209-213. https://doi.org/10.1016/0038-0717(88)90038-7

Ndoye I., Dreyfus B., \& M., B. (1996). Sesbania rostrata as green manure for lowland rice in Casamance (Senegal). Tropical Agriculture (Trinidad), 73(3), 234-237. https://www.researchgate.net/publication/32971749

Ndungu J. N. and Boland D. (1994). Sesbania seed collections in Southern Africa Developing a model for collaboration between a CGIAR Centre and NARS. Agroforestry Systems, 27, 129-143. https://doi.org/10.1007/BF00705470

NifTAL Nitrogen Fixation for Tropical Agricultural Legumes (NifTAL) Project. USA. (1985). Legume inoculants and their use. A Pocket Manual (Food and Agriculture Organization of the United Nations (ed.)). Food \& Agriculture Org. https://www.worldcat.org/title/legume-inoculants-and-their-use-a-pocket-manual/oclc/1131330060 in Ethiopia. African Journal of Plant Science, 7(10), 468-475. https://doi.org/10.5897/AJPS2012.0716 
Nirmal S. A., Bairagi, J. H., Patil, A. N., Pal, S. C., Upasani, C. D., \& Mandal, S. C. (2012). Antinociceptive activity of Sesbania sesban (Linn) wood extracts, a preliminary study. Indian Journal of Experimental Biology, 50(1), 61-64.

Nwilo P. C., Olayinka, D. N., Okolie, C. J., Emmanuel, E. I., Orji, M. J., \& Daramola, O. E. (2020). Impacts of land cover changes on desertification in northern Nigeria and implications on the Lake Chad Basin. Journal of Arid Environments, 181(March), 104190. https://doi.org/10.1016/j.jaridenv.2020.104190

Orwa C., Mutua, A., R, K., Jamnadass R, \& S Anthony. (2009). Agroforestree Database:a tree reference and selection guide version 475 4.0: Sesbania sesban (L.) Merr. Fabaceae - Papilionoideae. In Agroforestry Database. http://www.worldagroforestry.org/sites/treedbs/treedatabases.asp

Pandhare Ramdas B., Sangameswaran B., B., M. P., \& G., K. S. (2011). Antidiabetic activity of aqueous leaves extract of Sesbania sesban (L) Merr. in streptozotocin induced diabetic rats. Avicenna Journal of Medical Biotechnology, 3(1), 37-43. https://doi.org/10.1093/neuonc/nos096

Patra A. K., Chhonkar P. K., \& Khan M. A. (2006). Effect of green manure Sesbania sesban and nitrification inhibitor encapsulated calcium carbide (ECC) on soil mineral-N , enzyme activity and nitrifying organisms in a rice - wheat cropping system. European Journal of Soil Biology, 42, 173-180. https://doi.org/10.1016/j.ejsobi.2005.12.007

Patrice Jullien de Pommerol. (1997). L'arabe tchadien : émergence d'une langue véhiculaire. Karthala Éditions, coll. «Dictionnaires et langues », France. p. 174. https://www.amazon.fr/Livres-Patrice-Jullien-de-

Pommerol/s?rh=n\%3A301061\%2Cp_27\%3APatrice+Jullien+de+Pommerol\%0AAffiner

Polak, R., Phillips, E. M., \& Campbell, A. (2015). Legumes: Health Benefits and Culinary Approaches to Increase Intake. Clin Diabetes, 33(4), 198-205. https://doi.org/10.2337/diaclin.33.4.198

Ribeiro J. H.C., Fonseca, C. R., \& Carvalho, F. A. (2017). The woody vegetation of quartzite soils in a mountain landscape in the atlantic forest domain (south-eastern Brazil): Structure, diversity and implications for conservation. Edinburgh Journal of Botany, 74(1), 15-32. https://doi.org/10.1017/S096042861600024X

Richard White, \& and International Legume Database and Information Service. (2018). Sesbania sesban (L.) Merr. International Legume Database and Information Service (ILDIS). https://ildis.org/cgi-

bin/Araneus.pl?version 10.01\&LegumeWeb\&tno 1556\&genus Sesbania\&species sesban

Robert J Van der Plas, \& Mahamat Ali Abdel-Hamid. (2005). Can the woodfuel supply in sub-Saharan Africa be sustainable? The case of N'Djaména, Chad. Energy Policy, 33(3), 297-306. https://doi.org/10.1016/j.enpol.2003.08.001

Rochester I. J., Peoples, M. B., Hulugalle, N. R., Gault, R. R., \& Constable, G. A. (2001). Using legumes to enhance nitrogen fertility and improve soil condition in cotton cropping systems. Field Crops Research, 70(1), 27-41. https://doi.org/10.1016/S03784290(00)00151-9

Roothaert R. L., \& Paterson R. T. (1997). Recent work on the production and utilization of tree fodder in East Africa. Animal Feed Science and Technology, 69(1-3), 39-51. https://doi.org/10.1016/S0377-8401(97)81621-5

Rukangira Ernest. (2001). Medicinal Plants and Traditional Medicine in Africa: Constraints and Challenges. Conserve Africa 
Samajdar Saptarshi, \& Ghosh Amiya Kr. (2017). Pharmacological effects of Sesbania sesban Linn : An overview. PharmaTutor, 5(7), 16-21. https://www.pharmatutor.org/articles/magazines/articles/july-2017/pharmacological-effects-of-sesbaniasesbanlinnan-overview

Semba, R. D., Ramsing, R., Rahman, N., Kraemer, K., \& Bloem, M. W. (2021). Legumes as a sustainable source of protein in human diets. Global Food Security, 28, 100520. https://doi.org/10.1016/j.gfs.2021.100520

Shaikh Sajid R., Vijay Pawar T., \& Md. Rageeb Md. Usman. (2012). Anti-Inflammatory activity of Sesbania sesban (L) Merr. International Research Journal of Pharmacy, 3(1), 176-180.

https://pdfs.semanticscholar.org/1822/c44801e7e849685ddf3ce9310e702cc91d5d.pdf

Sharma Radhey Shyam, Asif Mohmmed, Mishra, V., \& Cherukuri Raghavendra Babu. (2005). Diversity in a promiscuous group of rhizobia from three Sesbania spp. colonizing ecologically distinct habitats of the semi-arid Delhi region. Research in Microbiology, 156(1), 57-67. https://doi.org/10.1016/j.resmic.2004.08.009

Shiv Pal Singh. (1990). Fertility Control of Female through Sesbani Sesbian Seeds. Journal of Research and Education in Indian Medicine, 9(4), 27-32. https://pdfs.semanticscholar.org/.../1ce2e6e2570d7d0d42eace6065...\%0A

Shun-ching Lee. (1960). The Study on the effect of light to the development and growth of Sesbania Sesban (Merr.). Taiwania

Siaw, D. E. K. A., Osuji, P. O., \& Nsahlai, L. V. (1993). Evaluation of multipurpose tree germplasm the use of gas production and rumen degradation characteristics. The Journal of Agricultural Science, 120(3), 319-330. https://doi.org/10.1017/S0021859600076486

Sileshi G. W., Akinnifesi, F. K., Ajayi, O. C., \& Place, F. (2008). Meta-analysis of maize yield response to woody and herbaceous legumes in sub-Saharan Africa. Plant and Soil, 307(1-2), 1-19. https://doi.org/10.1007/s11104-008-9547-y

Sileshi G. W., Mafongoya, P. L., Akinnifesi, F. K., Phiri, E., Chirwa, P., Beedy, T., Makumba, W., Nyamadzawo, G., Njoloma, J., Wuta, M., Nyamugafata, P., \& Jiri, O. (2014). Agroforestry: Fertilizer Trees. Encyclopedia of Agriculture and Food Systems, 1, 222-234. https://doi.org/10.1016/B978-0-444-52512-3.00022-X

Sileshi W. Gudeta, Debusho L. K., \& Akinnifesi Festus K. (2012). Can integration of legume trees increase yield stability in rain-fed maize cropping systems in Southern Africa ? Agronomy Journal, 104(5), 1-21. https://doi.org/10.2134/agronj2012.0063

Singh S., Ladha, J. K., Gupta, R. K., Bhushan, L., Rao, A. N., Sivaprasad, B., \& Singh, P. P. (2007). Evaluation of mulching, intercropping with Sesbania and herbicide use for weed management in dry-seeded rice (Oryza sativa L.). Crop Protection, 26(4), 518-524. https://doi.org/10.1016/j.cropro.2006.04.024

Sobere Augustin Traore. (1991). Contribution à l'étude de la nodulation de tige par rhizobium chez une légumineuse aquatique, Sesbania pubescens. [p. 98. Maitrise en Sciences Agronomique. Faculté des Sciences et Techniques, département de 
Tatiya Anil U., Dande, P. R., Mutha, R. E., \& Surana, S. J. (2013). Effect of saponins from of Sesbania sesban L. (Merr) on acute chronic inflammation in experimental induced animals. Journal of Bio-Sciences, 13(3), 123-130. https://doi.org/10.3923/jbs.2013.123.130

Taugourdeau Simon, Daget, P., Chatelain, C., Mathieu, D., Juanes, X., Huguenin, J., \& Ickowicz, A. (2019). FLOTROP, a massive contribution to plant diversity data for open ecosystems in northern tropical Africa. Scientific Data, 6(1), 4-11. https://doi.org/10.1038/s41597-019-0120-8 Improving Soil Fertility and Increasing Crop Productivity in Northeast Thailand. In: Community Watershed Management for Sustainable Intensification in Northeast Thailand. 70-12. http://oar.icrisat.org/6538/ effects-

World Agroforestry Centre. (2002). Sesbania sesban. In World Agroforestry Centre.

Zulfiqar Ali, Ashraf, M., Al-Qurainy, F., Salim Khan, M., \& Akram, N. A. (2015). Appraising drought tolerance in local accessions of 